\title{
Genetic diversity in natural populations of Hancornia speciosa Gomes: Implications for conservation of genetic resources
}

\section{Diversidade genética em populações de Hancornia speciosa Gomes: Implicações para a conservação dos recursos genéticos}

\author{
Cristiane Gouvêa Fajardo ${ }^{1 *}$, Daniel Ferreira da Costa', \\ Kyvia Pontes Teixeira das Chagas ${ }^{1}$, Fábio de Almeida Vieira ${ }^{1}$
}

\author{
'Universidade Federal do Rio Grande do Norte/UFRN, Unidade Acadêmica Especializada em Ciências Agrárias, Macaíba, RN, Brasil \\ ${ }^{*}$ Corresponding author: genegoista00@gmail.com \\ Received in August 14, 2018 and approved in October 26, 2018
}

\begin{abstract}
The continuing fragmentation of forests has been a threat to the maintenance of genetic resources. Genetic diversity is fundamental to the survival of species in natural environments in the long term, as well as being the basis for genetic improvement. The objective of this study was to evaluate the genetic diversity in natural populations of Hancornia speciosa and to contribute to the development of conservation strategies. We sampled 105 individuals of $H$. speciosa, distributed in seven populations. The ISSR (Inter-Simple Sequence Repeat) markers provided 70 loci, of which $81 \%$ were polymorphic. The mean genetic diversity of Nei $(h)$ was 0.19 , and the Shannon index ( $/$ ) was 0.27 . The $h$ and $/$ diversity indices ranged respectively from 0.16 to 0.24 in the PAD (Parque das Dunas) population and from 0.21 to 0.29 in MAC (Macaíba) population. Resulting from a Bayesian analysis, the genotypes were divided into four groups $(K=4)$. The allelic diversity patterns observed indicated the occurrence of the genetic bottleneck in all populations, according to the stepwise mutation model (SMM). The infinite allele model (IAM) revealed an imbalance between mutation and genetic drift only in the PAD population. Genetic conservation strategies for $\mathrm{H}$. speciosa should cover each genetic group that was differentially structured. We recommend in situ conservation and the creation of germplasm banks, especially with the PAD population which demonstrated the lower genetic diversity and decreased effective population size according to the two mutational models.
\end{abstract}

Index terms: Apocynaceae; genetic structure; genetic bottleneck; ISSR; mangabeira.

\begin{abstract}
RESUMO
A contínua fragmentação das florestas tem sido uma ameaça à manutenção dos recursos genéticos. A diversidade genética é fundamental para a sobrevivência das espécies em ambientes naturais a longo prazo, além de ser a base para o melhoramento genético. O objetivo deste estudo foi avaliar a diversidade genética em populações naturais de Hancornia speciosa e contribuir para o desenvolvimento de estratégias de conservação. Foram amostrados 105 indivíduos de $H$. speciosa, distribuídos em sete populações. Os marcadores ISSR (Entre Sequências Simples Repetida) forneceram 70 loci, dos quais $81 \%$ foram polimórficos. A diversidade genética média de Nei $(h)$ foi de 0,19 e o índice de Shannon ( $($ ) foi de 0,27 . Os índices de diversidade $h$ e / variaram respectivamente de 0,16 a 0,24 na população de PAD (Parque das Dunas) e de 0,21 a 0,29 na população de MAC (Macaíba). De acordo com a análise bayesiana, os genótipos foram divididos em quatro grupos $(K=4)$. Os padrões observados para diversidade alélica indicaram a ocorrência de gargalo genético em todas as populações, de acordo com o modelo de passos de mutação (SMM). O modelo do alelo infinito (IAM) revelou um desequilíbrio entre a mutação e a deriva genética apenas na população de PAD. Estratégias de conservação genética para H. speciosa devem abranger cada grupo genético diferencialmente estruturado. Recomendamos a conservação in situ e a criação de bancos de germoplasma, especialmente com a população PAD que demonstrou a menor diversidade genética e decréscimo no tamanho efetivo da população conforme os dois modelos mutacionais.
\end{abstract}

Termos para indexação: Apocynaceae; estrutura genética; gargalo genético; ISSR; mangabeira.

\section{INTRODUTION}

Hancornia speciosa Gomes belongs to the family Apocynaceae, one of the largest families of angiosperms, with about 366 genera and more than 5,100 species (Nazar et al., 2013; Endress; Liede-Schumann; Meve, 2014). The species is known as mangabeira and has a wide distribution in Brazil. H. speciosa is reported from the coastal tableland of the north east to the Cerrado of the mid-west, south east and north regions (Koch et al., 2015). The genus Hancornia is considered monotypic since it possesses only one species (Almeida et al., 2016). In the north east region of Brazil, towards the mid-west and the north, $H$. speciosa var. speciosa Gomes occurs; in the south east $H$. speciosa var. maximilliani (A. DC.) and H. speciosa var. lundii (A. DC.) occur; in the mid-west $H$. speciosa var. cuyabensis Malme occurs; and in the Central Region of Brazil both H. speciosa var. gardneri (A. DC. Muell. Arg.) 
and H. speciosa var. pubescens (Nees \& Martius) Muell. Arg. occur (Collevatti et al., 2016).

North east Brazil is the region that produces the most fruit, as known as mangaba, and the collection is a predominantly extractive activity (IBGE, 2016). The fruits are consumed mainly by the local populations in the region where the tree occurs, with a wide diversity of uses in the diet (Oliveira et al., 2017). Besides the socioeconomic role, fruit collection and commercialization are a significant economic activity that contributes to the income of the communities (Sá; Lédo; Lédo, 2011). In fact, between 2015 and 2016, the quantity of fruit produced 1,600 tonnes in Brazil, with the value of about 3.65 million BRL (equivalent to about 1.10 million USD) (IBGE, 2016). In addition to the sweet fruit, the roots, barks and latex have the medicinal use (Oliveira et al., 2017). Latex presents the biotechnological potential for the development of new drugs, revealing a potential for future horticultural and breeding programs (Arruda et al., 2016).

Strategies for the maintenance of forest resources have been increasingly important due to the rapid loss of natural habitats (Nascimento et al., 2012). The remaining forests are widely fragmented and mostly located in areas of monoculture and pasture (Moraes; De Mello; Toppa, 2017). Thus, the gene flow from the pollen exchange between populations can be altered, as well as seed dispersal (Vieira; Carvalho, 2008). In the north east of Brazil, real estate speculation and the establishment of monocultures such as coconut, sugar cane, extensive livestock breeding, and various extractive activities are constant threats to the genetic integrity of the natural populations of $H$. speciosa. Efforts are needed to reconcile conservation of the genetic resource and the sustainable use of $H$. speciosa.

Genetic diversity is represented by distinct alleles and genotypes found within and among the populations. This variability is reflected in physiological and morphological characteristics, being the basis of the evolutionary potential of the species in response to human disturbances (Mimura et al., 2017). In this sense, PCRbased molecular markers (polymerase chain reaction) are useful tools in detecting both polymorphism between individuals and numerous variations at chromosomal levels (Adhikari et al., 2017). Studies related to the quantification of the genetic diversity of $H$. speciosa are continuing (Costa et al., 2015; Soares et al., 2017). Further research is needed to provide a broad overview of the geographic distribution of genetic diversity (Almeida et al., 2016), with implications for genetic conservation and breeding.
Among the factors that may influence the distribution of genetic diversity is the reproductive system of the species, which is closely related to the flow of pollen and seeds among populations. Theoretically, the higher the flow, the less genetic differentiation there will be between the populations. On the other hand, low gene interchange increases the differentiation among the populations (Ellstrand, 2014). The present work aimed to evaluate the distribution of genetic diversity between populations and the levels of genetic diversity and structuring.

\section{MATERIAL AND METHODS}

\section{Target species}

H. speciosa has nocturnal anthesis, as well as an allogamous and self-incompatible reproductive system, hence being an outcrossing species (Darrault; Schlindwein, 2005; Collevatti et al., 2016). It has mass flowering, which can promote a geitonogamy (self-pollination) (Pinto; Oliveira; Schlindwein, 2008). H. speciosa requires biotic agents, mainly moths, for pollination and hence for fruit production (Collevatti et al., 2016). It presents, predominantly, zoochory dispersion, with the hoary fox (Lycalopex vetulus) being one of its dispersers (Dalponte; Lima, 1999). The seeds are recalcitrant, and the propagation by asexual pathways is uncommon (Santos et al., 2015), which hinders the production of seedlings and natural regeneration.

\section{Study site and sampling}

All the populations sampled are in the eastern coastal region of the State of Rio Grande do Norte, which is in the Atlantic Forest domain (Figure 1).

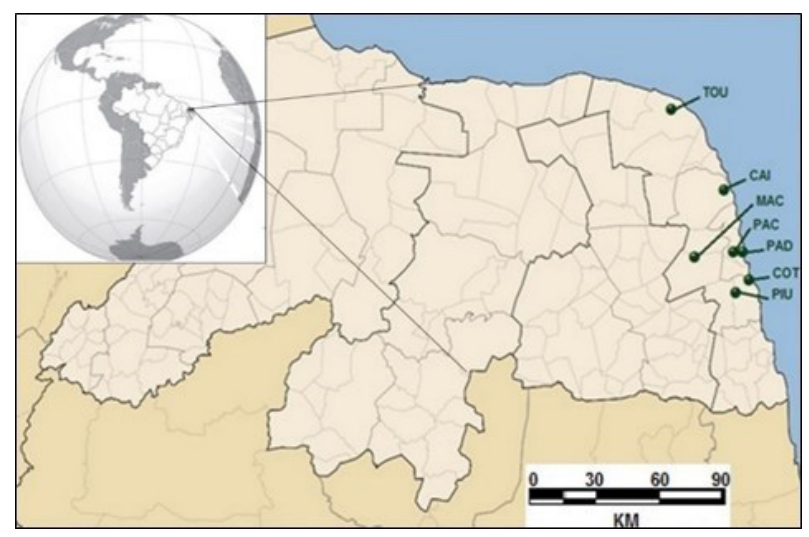

Figure 1: Geographical location of populations of Hancornia speciosa sampled in north eastern Brazil, in the State of Rio Grande do Norte. The codes and coordinates of the sampled populations are shown in Table 1. 
The region is characterized as coastal tableland, where the characteristic vegetation is the Semi-deciduous Seasonal Forest (Veloso; Rangel Filho; Lima, 1991). Usually the soils are deep and of low natural fertility. The region suffers intense anthropogenic action due to the large human population density and agricultural activities. The $H$. speciosa populations of the Parque da Cidade (PAC) and of the Parque das Dunas (PAD) are the only ones that are in areas of permanent protection. The other populations are subject to greater levels of both human impact and the effects of extraction of trees and fruit.

Fifteen adult individuals were sampled in each population, identified by the presence of flowers or fruits (Table 1). The smallest geographical distance between the populations is $3.6 \mathrm{~km}$ between PAC and PAD. The largest distance is between the populations of PIU and TOU, separated by $92.1 \mathrm{~km}$ (Table 2).

\section{DNA extraction, PCR and electrophoresis}

Samples were removed from the stem tissue in the cambial region and packed in $2 \mathrm{~mL}$ plastic tubes, containing CTAB 2X. Approximately $250 \mathrm{mg}$ of the stem tissue was used for the extraction, according to the method described by Doyle and Doyle (1987), with some modifications. PCR was performed on a Veriti ${ }^{\mathrm{TM}}$ Thermocycler (Applied Biosystems, USA) following the protocol of Costa et al. (2015). The ISSR primers used were the ISSR UBC808, UBC810, UBC826, UBC827, UBC841 and UBC842, which provided the best amplification profile and larger numbers of loci for H. speciosa (Costa et al., 2015).

The electrophoresis was undertaken on $1.5 \%$ agarose gel $(\mathrm{v} / \mathrm{v})$, in TAE buffer $(1.0 \mathrm{X}$, Tris-Acetate-EDTA) and $100 \mathrm{~V}$. The DNA molecular weight marker utilised was $1 \mathrm{~kb}$. The gels were photographed with ultraviolet light in Box ${ }^{\mathrm{TM}}$ VX2 (Vilber Lourmat, France), revealing DNA fragments stained with GelRed ${ }^{\mathrm{TM}}$ (Biotium, USA).

Table 1: Sampled populations of Hancornia speciosa, population code (as in Figure 1), sample size, geographic coordinates and altitude (m).

\begin{tabular}{ccccc}
\hline Population & County & Code & Lat. /Long. & Altitude \\
\hline Caiana & Ceará Mirim & CAI & $5^{\circ} 35^{\prime} 21^{\prime \prime} \mathrm{S} 35^{\circ} 16^{\prime} 27^{\prime \prime O}$ & 45 \\
Cotovelo & Parnamirim & COT & $5^{\circ} 57^{\prime} 58^{\prime \prime} \mathrm{S} 35^{\circ} 08^{\prime} 31^{\prime \prime O}$ & 23 \\
Macaíba & Macaíba & MAC & $5^{\circ} 53^{\prime} 19^{\prime \prime} \mathrm{S} 35^{\circ} 21^{\prime} 29^{\prime \prime} \mathrm{O}$ & 46 \\
Parque da Cidade & Natal & PAC & $5^{\circ} 50^{\prime} 49^{\prime \prime} \mathrm{S} 35^{\circ} 13^{\prime} 48^{\prime \prime O}$ & 57 \\
Parque das Dunas & Natal & PAD & $5^{\circ} 51^{\prime} 18^{\prime \prime} \mathrm{S} 35^{\circ} 11^{\prime \prime} 54^{\prime \prime O}$ & 40 \\
Pium & Nísia Floresta & PIU & $6^{\circ} 00^{\prime} 20^{\prime \prime} \mathrm{S} 35^{\circ} 11^{\prime} 54^{\prime \prime O}$ & 63 \\
Touros & Touros & TOU & $5^{\circ} 13^{\prime} 41^{\prime \prime} \mathrm{S} 35^{\circ} 30^{\prime} 28^{\prime \prime O}$ & 25 \\
\hline
\end{tabular}

Table 2: Genetic diversity in seven populations of Hancornia speciosa. The columns represent polymorphic loci $(L)$, percentage of polymorphic loci $(\% \mathrm{P})$, number of allele $(n a)$, effective number of alleles $(\mathrm{Ne})$, genetic diversity of Nei $(h)$, Shannon index $(I)$. The values shown in parentheses indicate the standard errors.

\begin{tabular}{cccccc}
\hline Population & L/ \%P & $n a(\mathrm{se})$ & $N e$ & $h$ & $l$ \\
\hline CAI & $31 / 44$ & $1.44(0.06)$ & $1.34(0.05)$ & $0.19(0.03)$ & $0.27(0.04)$ \\
COT & $29 / 41$ & $1.41(0.06)$ & $1.34(0.05)$ & $0.18(0.03)$ & $0.26(0.04)$ \\
MAC & $33 / 47$ & $1.47(0.06)$ & $1.38(0.05)$ & $0.21(0.03)$ & $0.29(0.04)$ \\
PAC & $32 / 46$ & $1.46(0.06)$ & $1.35(0.05)$ & $0.19(0.03)$ & $0.28(0.04)$ \\
PAD & $30 / 43$ & $1.43(0.06)$ & $1.28(0.05)$ & $0.16(0.03)$ & $0.24(0.04)$ \\
PIU & $30 / 43$ & $1.43(0.06)$ & $1.37(0.05)$ & $0.20(0.03)$ & $0.28(0.04)$ \\
TOU & $32 / 46$ & $1.46(0.06)$ & $1.35(0.05)$ & $0.20(0.03)$ & $0.28(0.04)$ \\
Total & $57 / 81$ & $1.81(0.05)$ & $1.49(0.04)$ & $0.29(0.02)$ & $0.43(0.03)$ \\
Average & $31 / 44$ & $1.44(0.01)$ & $1.35(0.01)$ & $0.19(0.01)$ & $0.27(0.01)$ \\
\hline
\end{tabular}




\section{Diversity and genetic structure}

The genetic diversity was estimated using the POPGENE 1.3 software (Yeh; Boyle, 1997), obtaining the number of alleles observed $(n a)$, number of effective alleles $(n e)$, genetic diversity of Nei $(h)$ and the Shannon Index $(I)$. The genetic diversity indexes ( $h$ and $l$ ) were submitted to ANOVA (Analysis of Variance) using Past 3.20 program (Hammer; Harper; Ryan, 2001) to verify the statistical difference between the populations. It was used the KruskalWallis ANOVA for non-parametric data, indicated by previous analyses using the Lilliefors normality test.

The analysis of molecular variance (AMOVA) was performed using the ARLEQUIN 3.5.2 software (Excoffier; Lischer, 2010). The correlation between the geographic distance $(\mathrm{km})$ and the genetic distance $\left(G_{\mathrm{ST}}\right)$ was evaluated by the Mantel $\left(r_{\mathrm{M}}\right)$ test using GenAlex 6.503 software (Peakall; Smouse, 2012). The significance of the $r_{\mathrm{M}}$ test was obtained through a Monte Carlo test with 999 permutations.

The Bayesian analysis was performed to estimate the number of genetic groups $(K)$ using the Structure 2.2 software (Pritchard; Stephens; Donnelly, 2000). Genetic groups ranged from $K=1$ to $K=7$. The admixture ancestry model was used, based on the frequency of the correlated alleles. Ten independent runs were performed for each $K$. The runs were performed with 500,000 Monte Carlo simulations via Cadeia Markov (MCMC) and burn-in of 250,000. The number of genetic groups $(K)$ was identified according to the model Log-likelihood of probability $\operatorname{LnP}(K)$ plus $\Delta K$ method (Evanno; Regnaut; Goudet, 2005) as implemented in the Structure Harvester program (Earl; vonHoldt, 2012).

\section{Genetic bottlenecks}

The Bottleneck 1.2.02 software (Luikart; Cornuet; 1999) was used to verify if there was a recent decrease in the population size of the species (within the last tens of generations, Van Rossum; Prentice, 2004). The infinite allele model (IAM) and stepwise mutation model (SMM) were used to infer the presence of a genetic bottleneck. According to Luikart and Cornuet (1998), the most suitable model for ISSR primers would be an intermediary between IAM and SMM. Therefore, both models are recommended for such analysis. The signal test $(\alpha=0.05)$ was used to indicate the presence of significant genetic bottlenecks.

\section{RESULTS AND DISCUSSION}

\section{Genetic diversity and structuring}

The total number of loci observed was 70 , of which $57(81 \%)$ were polymorphic. The average value obtained for the effective number of alleles (ne) was 1.345, the average genetic diversity of Nei $(h)$ was 0.19 , and the average Shannon index ( $I$ ) was 0.27 (Table 3 ).

The number of polymorphic loci of the sampled populations was low, ranging from $29(41 \%)$ in COT to $33(47 \%)$ in MAC. This low index is indicative of low genetic diversity. According to the Kruskal-Wallis test $(H)$, the seven populations showed no statistical differences between the genetic diversity indexes of $h(H=1.604, P$ $=0.925)$ and $I(H=1.604, P=0.925)$.

The $h$ value for $H$. speciosa (0.19) was lower than expected for long-lived perennial and outcrossing species (0.25 and 0.27, respectively) (Nybom, 2004). The differences in genetic diversity indices among species are generally associated with the unique life history of each species (Fajardo; Vieira; Molina, 2014; Costa et al., 2015; Pinheiro et al., 2017). For example, Souza and Lovato (2010) studied two species of the genus Dimorphandra and found contrasting diversity indices. The species $D$. mollis, which has a high demographic density, presented average values of $h(0.12)$

Table 3: Estimates of genetic distances of $\mathrm{Nei}\left(G_{\mathrm{ST}}\right)$ below the diagonal, and geographical distance $(\mathrm{km})$ above the diagonal, between the populations of Hancornia speciosa. The minimum and maximum values are represented in bold type.

\begin{tabular}{rrrrrrrr}
\hline & CAI & COT & MAC & PAC & PAD & PIU & TOU \\
\hline CAI & 0 & 44.17 & 34.39 & 28.87 & 30.52 & 46.36 & 47.62 \\
COT & 0.14 & 0 & 25.40 & 16.40 & 13.77 & 7.58 & 91.12 \\
MAC & 0.10 & 0.10 & 0 & 14.90 & 18.10 & 21.72 & 74.92 \\
PAC & 0.21 & 0.26 & 0.23 & 0 & 3.65 & 17.45 & 75.02 \\
PAD & 0.12 & 0.14 & 0.07 & 0.199 & 0 & 16.16 & 77.34 \\
PIU & 0.10 & 0.11 & 0.13 & 0.25 & 0.20 & 0 & 92.14 \\
TOU & 0.05 & 0.13 & 0.07 & 0.21 & 0.25 & 0.12 & 0 \\
\hline
\end{tabular}


and $I(0.18)$, while the species $D$. wilsonii, at risk of extinction, presented lower average values of $h(0.05)$ and $I(0.08)$.

Costa, Silva and Lédo (2011), using dominant RAPD markers in $H$. speciosa, obtained mean values for $\mathrm{h}$ of 0.17 and $\mathrm{I}$ of 0.25 , which are similar to the means found in the present study. The reduced values of genetic diversity in $H$. speciosa should be monitored and quantified in several other populations, as they can reflect the anthropogenic pressure and genetic erosion (Yokomizo; Maia; Da Trindade, 2017).

The AMOVA revealed more variation within the populations $(75 \%)$ than between them $(25 \%)$ (Table 4$)$. The values obtained are in accordance with the pattern found in other studies with cross-pollinating, tree species (Nybom, 2004; Costa; Silva; Lédo, 2011; Pinheiro et al., 2017). The genetic diversity maintained within and between populations is a function of historical events and recent evolutionary processes (Lee et al., 2002). Crossfertilized species tend to retain a higher genetic diversity within populations (Nybom, 2004). Endangered species that have low population density present higher variability among populations than within them, due to loss of alleles by genetic drift (Souza; Lovato, 2010).

The mean $G_{\mathrm{ST}}$ was 0.16 . The PAD and TOU populations showed the highest genetic distance $\left(G_{\mathrm{ST}}=0.25\right)$, while the TOU and CAI populations were more genetically similar (0.05) (Table 2). However, the Mantel test indicated an absence of correlation between genetic and geographic distance matrices $(r=-0.19 ; P=0.30)$. These results indicate a random distribution of genotypes among populations and currently are not associated with isolation by distance. Probably the fragmentation and spatial isolation of the populations are relatively recent events and so have not created a pattern of geographic isolation of genotypes. Although the dispersal of pollen by moths is short-distance, the dispersion of $H$. speciosa seeds by hoary foxes could have contributed to the maintenance of the historical gene flow among populations.

\section{Bayesian analysis}

Four genetic groups $(K=4$, Figure 2$)$ were observed, indicated by the highest values of $\operatorname{LnP}(K)$ and $\Delta K$. The seven populations sampled were structured in four distinct groups (Figure 3).

Table 4: Molecular analysis of variance (AMOVA) in populations of Hancornia speciosa. The columns indicate $d f$ : degrees of freedom and SS sum of squared deviations, and $\Phi_{S T}$ : is the genetic differentiation.

\begin{tabular}{crccc}
\hline Source of variation & $d f$ & SS & Variance component & Total variance (\%) \\
\hline Among populations & 6 & 119.4 & 1.10 & 25 \\
Within populations & 98 & 327.7 & 3.34 & 75 \\
\hline Total & 104 & 6.34 & 4.45 & 100 \\
\hline$\Phi_{\text {ST }}$ & 0.25 & & & \\
\hline
\end{tabular}

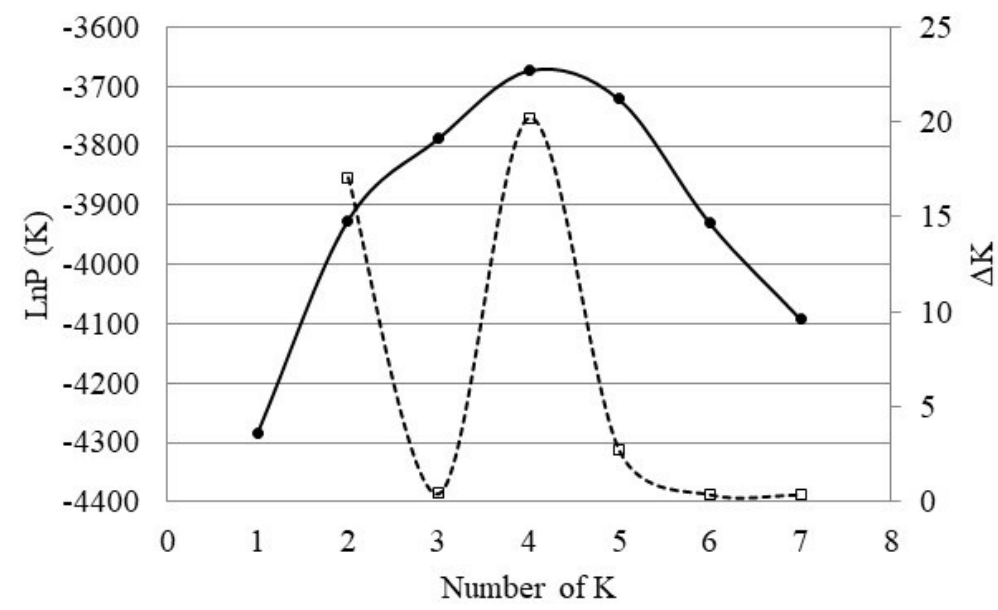

Figure 2: Bayesian analysis indicating $K=4$ according to the average probabilities of $\operatorname{LnP}(K)$ and $\Delta K$ (Evanno, Regnaut and Goudet, 2005). 
The PAD population presented a low proportion of distinct genotypes, reunited in a single group, confirming its larger differentiation. The same was observed for COT population. The CAI, PIU and MAC populations, in addition to PAC and TOU, can be seen to be more genetically similar. The genetic structure observed is consistent with the Mantel test, which showed no relation between the geographical and genetic distance of the populations.

\section{Genetic bottleneck}

All populations presented significant bottlenecks in the SMM model (Table 5). The PAD population presented a significant bottleneck in both IAM and SMM models. Recent decreases in effective population size favour a faster reduction in allelic richness than in heterozygosity. This effect is a consequence of the imbalance between mutation and genetic drift (Cornuet; Luikart, 1996). The identification of populations that have gone through a genetic bottleneck is fundamental for the adoption of strategies that aim to circumvent the effects of an effective reduction of population size and the risk of extinction (Lee et al., 2002).

Information about the levels and distribution of genetic diversity are essential for the successful management and preservation of populations of endangered species (Fajardo; Vieira; Molina, 2016). The scarcity of studies related to the reproductive ecology of the species is another important fact to be considered when aiming to conserve genetic resources. Being a self-incompatible species, knowledge of the distribution and habits of its dispersers and pollinators are essential. These studies are necessary to support the development of strategies that aim at maintaining the reproductive dynamics of the $H$. speciosa in its wide geographical range.

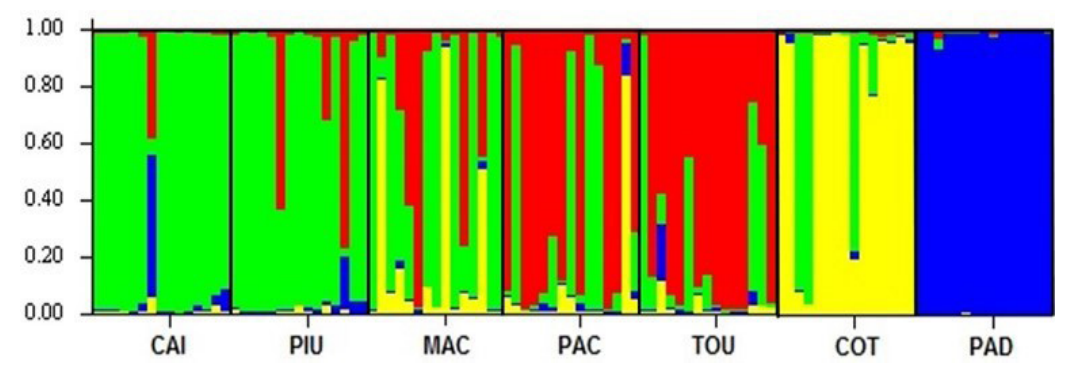

Figure 3: Genetic structure according to the Bayesian analysis and proportion of the genotypes in the seven populations sampled. Populations are delimited by the dark vertical bar. The four different colours indicate the four groups.

Table 5: Bottleneck tests for the populations of Hancornia speciosa using IAM and SMM models. The columns are $n=$ expected number of loci with excess heterozygosity under the respective model; $\mathrm{Hd} / \mathrm{He}=$ number of loci with a deficit of heterozygosity and excess heterozygosity; $P=$ probability; * and ** = significant at the 5 and $1 \%$ probability, respectively.

\begin{tabular}{ccccccc}
\hline \multirow{2}{*}{ Populações } & \multicolumn{3}{c}{ IAM } & \multicolumn{3}{c}{$S M M$} \\
\cline { 2 - 7 } & $n$ & $H d / H e$ & $\mathrm{P}$ & $n$ & $H d / H e$ & $P$ \\
\hline CAI & 32 & $41 / 28$ & 0.21 & 39 & $41 / 28$ & $0.00^{* *}$ \\
COT & 31 & $41 / 28$ & 0.26 & 38 & $41 / 28$ & $0.01^{* *}$ \\
MAC & 32 & $39 / 30$ & 0.33 & 39 & $40 / 29$ & $0.01^{*}$ \\
PAC & 31 & $41 / 28$ & 0.24 & 38 & $43 / 26$ & $0.00^{* *}$ \\
PAD & 32 & $47 / 22$ & $0.01 * *$ & 38 & $47 / 22$ & $0.00^{* *}$ \\
PIU & 32 & $40 / 29$ & 0.28 & 38 & $41 / 28$ & $0.01^{* *}$ \\
TOU & 32 & $40 / 29$ & 0.30 & 39 & $40 / 29$ & $0.01^{*}$ \\
\hline
\end{tabular}




\section{CONCLUSIONS}

The genetic diversity values presented lead to the recommendation that immediate in-situ conservation of the studied populations is required. The low levels of genetic diversity observed, the frequency of forest fragmentation, and of the increase of the anthropogenic activities are threats to the maintenance of the genetic resources of the H. speciosa populations. Besides, the occurrence of a significant genetic bottleneck in all populations suggests the need to create germplasm banks that capture the genetic diversity of this species. Thus, it can be possible to ensure the maintenance of ex-situ genetic variability so as to assist in genetic improvement of the in-situ populations of $H$. speciosa.

\section{ACKNOWLEDGEMENTS}

We thank the Conselho Nacional de Desenvolvimento Científico e Tecnológico $(\mathrm{CNPq})$ for providing scientific initiation scholarship for KPTC. This study was financed in part by the Coordenação de Aperfeiçoamento de Pessoal de Nível Superior - Brasil (CAPES) - Finance Code 001. We also thank CAPES for providing a Post-doctoral Scholarship Abroad for FAV, process no. 88881.118979/2016-01. Finally, we thank Professor Michael B. Usher for assistance in editing the English of the manuscript.

\section{REFERENCES}

ADHIKARI, S. et al. Application of molecular markers in plant genome analysis: A review. The Nucleus, 60(3):283-297, 2017.

ALMEIDA, L. M. et al. State of the art of scientific literature on Hancornia speciosa: Trends and gaps. Revista Brasileira de Fruticultura, 38(4):e-869, 2016.

ARRUDA, A. D. et al. Magabeira latex production evaluation in cerrado region of Goiás. Ciência Florestal, 26(3):939948, 2016.

COLLEVATTI, R. G. et al. Gene flow among Hancornia speciosa (Apocynaceae) varieties and hybrid fitness. Tree Genetics \& Genomes, 12(74):1-12, 2016.

CORNUET, J. M.; LUIKART, G. Description and power analysis of two tests for detecting recent population bottlenecks from allele frequency data. Genetics, 144:2001-2014, 1996.

COSTA, D. F. D. et al. Diversidade genética e seleção de iniciadores ISSR em uma população natural de mangaba
(Hancornia speciosa Gomes) (Apocynaceae). Revista Brasileira de Fruticultura, 37:970-976, 2015.

COSTA. T. S.; SILVA. A. V. C.; LÉDO. A. S. Diversidade genética de acessos do banco de germoplasma de mangaba em Sergipe. Pesquisa Agropecuária Brasileira, 46(5): 499-508, 2011.

DALPONTE, J. C.; LIMA. E. S. Disponibilidade de frutos e a dieta de Lycalopex vetulus (Carnivora - Canidae) em um cerrado de Mato Grosso. Brasil. Revista Brasileira de Botânica, 22(2):325-332, 1999.

DARRAULT, R. O.; SCHLINDWEIN. C. Limited fruit production in Hancornia speciosa (Apocynaceae) and pollination by nocturnal and diurnal insects with long mouth parts. Biotropica, 37(3):381-388, 2005.

DOYLE, J. J.; DOYLE, J. L. Isolation of plant DNA from fresh tissue. Focus, 12(1):13-15, 1987.

EARL, D. A.; VONHOLDT, B. M. Structure Harvester: A website and program for visualizing structure output and implementing the Evanno method. Conservation Genetics Resources, 4(2):359e361, 2012.

ELLSTRAND, N. C. Is gene flow the most important evolutionary force in plants? American Journal of Botany, 101(5):737753, 2014.

ENDRESS, M. E.; LIEDE-SCHUMANN. S.; MEVE. U. An updated classification for Apocynaceae. Phytotaxa, 159:175-194, 2014.

EVANNO, G.; REGNAUT, S.; GOUDET, J. Detecting the number of clusters of individuals using the software STRUCTURE: A simulation study. Molecular Ecology, 14:2611-2620, 2005.

EXCOFFIER, L.; LISCHER, H. E. L. Arlequin suite ver 3.5: A new series of programs to perform population genetics analyses under Linux and Windows. Molecular Ecology Resources, 10:564-567, 2010.

FAJARDO, C. G.; VIEIRA, F. A.; MOLINA, W. F. Conservação genética de populações naturais: Uma revisão para Orchidaceae. Biota Amazônia, 6:108-118, 2016.

FAJARDO, C. G.; VIEIRA, F. A.; MOLINA, W. F. Interspecific genetic analysis of orchids in Brazil using molecular markers. Plant Systematics and Evolution, 300:1825-1832, 2014.

HAMMER, Ø.; HARPER, D. A. T.; RYAN, P. D. Past: Paleontological statistics software package for education and data analysis. Palaeontologia Electronica, 4(1):1-9, 2001.

IBGE - INSTITUTO BRASILEIRO DE GEOGRAFIA ESTATÍSTICA. SIDRA - Banco de tabelas estatísticas. 2016. Available in: < https://sidra.ibge.gov.br>. Access in: April, 16, 2018. 
$\mathrm{KOCH}$, l. et al. Apocynaceae in Lista de Espécies da Flora do Brasil. 2015. Jardim Botânico do Rio de Janeiro. Available in: <http://floradobrasil.jbrj.gov.br/jabot/floradobrasil/ FB15558>. Access in: April, 19, 2018.

LEE, S. L. et al. Population genetics of Intsia palembanica (Leguminosae) and genetic conservation of Virgin Jungle Reserves in Peninsular Malaysia. American Journal of Botany, 89:447-459, 2002.

LUIKART, G.; CORNUET, J. M. Empirical evaluation of a test for identifying recently bottlenecked populations from allele frequency data. Conservation Biology, 12: 228-237, 1998.

LUIKART, G.; CORNUET, J. M. BOTTLENECK: A program for detecting recent effective population size reductions from allele data frequencies. 1999. Available in:< http://www1. montpellier.inra.fr/CBGP/software/Bottleneck/bottleneck. html>. Access in: November, 15, 2018.

MIMURA, M. et al. Understanding and monitoring the consequences of human impacts on intraspecific variation. Evolutionary Applications, 10(2):121-139, 2017.

MORAES, M. C. P.; DE MELLO, K.; TOPPA, R. H. Protected areas and agricultural expansion: Biodiversity conservation versus economic growth in the Southeast of Brazil. Journal of Environmental Management, 188:73-84, 2017.

NASCIMENTO, L. M. et al. Natural forest regeneration in abandoned sugarcane fields in northeastern Brazil: Floristic changes. Biota Neotropica, 12(4):84-97, 2012.

NAZAR, N. et al. The taxonomy and systematics of Apocynaceae: Where we stand in 2012. Botanical Journal of the Linnean Society, 17:482-490, 2013.

NYBOM, H. Comparison of different nuclear DNA markers for estimating intraspecific genetic diversity in plants. Molecular Ecology, 13:1143-1155, 2004.

OLIVEIRA, D. M. et al. Coletânea bibliográfica acadêmica sobre a mangabeira (Hancornia speciosa Gomes). Gaia Scientia, 11(3):212-231, 2017.

PEAKALL, R.; SMOUSE, P. E. GenAIEx 6.5: Genetic analysis in Excel. Population genetic software for teaching and research-an update. Bioinformatics, 28:2537-2539, 2012.

PINHEIRO, L. G. et al. Anthropization as a determinant factor in the genetic structure of Copernicia prunifera (Arecaceae). Genetics and Molecular Research, 16:1-14, 2017.
PINTO, C. E.; OLIVEIRA. R.; SCHLINDWEIN, C. Do consecutive flower visits within a crown diminish fruit set in massflowering Hancornia speciosa (Apocynaceae)? Plant Biology, 10(3):408-412, 2008.

PRITCHARD, J. K.; STEPHENS, M.; DONNELLY, P. Inference of population structure using multilocus genotype data. Genetics, 155:945-959, 2000.

SÁ, A. J.; LÉDO, A. S.; LÉDO, C. A. S. Conservação in vitro de mangabeira da região nordeste do Brasil. Revista Ciência Rural, 41(1):57- 62, 2011.

SANTOS, P. A. A. et al. Cryopreservation of the mangaba tree (Hancornia speciosa Gomes): A protocol for long-term storage. Acta Scientiarum-Agronomy, 37(3):289-296, 2015.

SOARES, F. S. et al. Diversity and genetic structure of mangabeira (Hancornia speciosa Gomes). A fruit specie from Cerrado. Semina-Ciencias Agrarias, 38(4):2479-2487, 2017.

SOUZA, H. A. V.; LOVATO, M. B. Genetic diversity and structure of the critically endangered tree Dimorphandra wilsonii and of the widespread in the Brazilian Cerrado Dimorphandra mollis: Implications for conservation. Biochemical Systematics and Ecology, 38:49-56, 2010.

VAN ROSSUM, F.; PRENTICE, H. C. Structure of allozyme variation in Nordic Silene nutans (Caryophyllaceae): Population size. geographical position and immigration history. Biological Journal of the Linnean Society, 81(3):357-371, 2004.

VELOSO, H. P.; RANGEL FILHO, A. L. R.; LIMA, J. C. A. Classificação da vegetação brasileira. Adaptada a um sistema universal. Rio de Janeiro: Editora IBGE - Departamento de Recursos Naturais e Estudos Ambientais, 1991. 124p.

VIEIRA, F. A.; CARVALHO, D. Genetic structure of an insectpollinated and bird-dispersed tropical tree in vegetation fragments and corridors: Implications for conservation. Biodiversity and Conservation, 17(10):2305-2321, 2008.

YEH, F. C.; BOYLE, T. J. B. Population genetic analysis of codominant and dominant marker and quantitative traits. Belgian Journal of Botany, 130:129-157, 1997.

YOKOMIZO, G. K. I.; MAIA. M. C. C.; DA TRINDADE. C. F.; Morphological dissimilarity among mangabeira tree populations from Amapá and Paraíba, Brazil. Revista Caatinga, 30(2):521-529, 2017. 